\title{
ANALISIS SISTEM PENGENDALIAN INTERNAL PERSEDIAAN BARANG DAGANGAN PADA PT. DAYA ANUGRAH MANDIRI CABANG MANADO
}

\author{
Brenda Meydita Lineke Kawatu ${ }^{1}$, Jantje J. Tinangon ${ }^{2}$, Natalia Y. T. Gerungai ${ }^{3}$ \\ 1, 2, 3Jurusan Akuntansi, Fakultas Ekonomi dan Bisnis, Universitas Sam Ratulangi, Jl. Kampus Bahu, Manado, \\ 95115, Indonesia
}

E-mail: brendamlkawatu@gmail.com

\begin{abstract}
Inventory is one of the important assets of the company. Therefore, internal control over inventory is needed to protect against the risk of theft, damage and fraud. This study aims to determine the internal control system for merchandise inventory implemented by PT. Daya Anugrah Mandiri Manado Branch in terms of the internal control component according to the coso (committee of sponsoring organizations). The method of analysis in this study uses qualitative methods by obtaining data through interviews and documentation and then conclusions are drawn. The results showed that the internal control system for merchandise inventory applied by PT. The overall grace of the Manado branch of Anugrah is already good. Companies should further enhance the security of inventory in the warehouse by installing cctv camera so that security is more secure, and the need for an accounting department that is specifically tasked with carrying out financial records and reporting.

Keywords: internal control; inventory; committee of sponsoring organizations
\end{abstract}

\section{PENDAHULUAN}

Perkembangan yang terjadi dalam dunia usaha seiring dengan berkembangnya teknologi telah memberikan pengaruh besar terhadap perkembangan ekonomi. Hal ini dapat dilihat dengan adanya persaingan yang semakin ketat sehingga mengharuskan setiap perusahaan untuk lebih memperluas usahanya dengan meraih pangsa pasar yang ada agar mampu bersaing. Persaingan tersebut dapat menjadi tantangan bagi pihak manajemen perusahaan untuk memikirkan alternatif terbaik yang akan dijadikan sebagai jalan keluar dalam memajukan perusahaan, salah satu cara dengan mengelola seoptimal mungkin sumber daya yang dimiliki.

Perusahaan dagang merupakan suatu organisasi yang melakukan kegiatan usaha dengan membeli barang dari pihak lain kemudian menjual kembali barang dagangan yang dibeli kepada konsumen, dengan tujuan untuk memperoleh keuntungan. Persediaan merupakan aset lancar dalam bentuk barang yang di maksudkan untuk dijual sebagai kegiatan operasional. Perusahaan harus dapat memperhitungkan jumlah persediaan yang optimal, tingkat persediaan yang berlebihan akan mengakibatkan timbulnya biaya pemeliharaan dan penyimpanan, serta tidak menutup kemungkinan terjadinya kerusakan namun sebaliknya jika jumlah persediaan terlalu sedikit akan menimbulkan hambatan bagi perusahaan dalam memenuhi kebutuhan konsumen.

Persediaan merupakan aset perusahaan yang memiliki potensi terhadap risiko terjadinya kerusakan maupun pencurian. Kehilangan barang dagangan dan kesalahan pencatatan seringkali menjadi masalah dalam hal persediaan dalam perusahaan. Perusahaan memerlukan pengendalian internal terhadap persediaan barang dagangan yang bertujuan untuk dapat melindungi dan memastikan persediaan dalam keadaan aman, serta dapat memberikan informasi yang andal dan benar, khususnya mengenai jumlah persediaan dalam laporan rugi laba perusahaan (Makaluas dan Pontoh, 2018). Committee of Sponsoring Organization (COSO) menguraikan lima komponen penting dalam pengendalian internal, 
yaitu lingkungan pengendalian, penilaian risiko, aktivitas pengendalian, informasi dan komunikasi, serta pengawasan. Perusahaan harus memperhatikan dan menerapkan secara efektif setiap komponen penting dari pengendalian internal agar mampu memberikan dampak positif bagi perusahaan sehingga dapat menghindari risiko-risiko berupa kesalahan ataupun kecurangan yang mungkin terjadi baik secara sengaja maupun tidak sengaja.

\section{TINJAUAN PUSTAKA}

Menurut Pontoh (2013:1), akuntansi adalah sebuah sistem informasi yang mengukur aktivitas bisnis, pemrosesan data menjadi laporan, dan mengkomunikasikan hasilnya pada para pengambil keputusan. Kartikahadi (2016:3) menyatakan bahwa akuntansi adalah suatu sistem informasi keuangan, yang bertujuan untuk menghasilkan dan melaporkan informasi yang relevan bagi berbagai pihak yang berkepentingan. Sujarweni (2016:1) mendefinisikan pengertian akuntansi manajemen adalah salah satu bidang ilmu dari akuntansi yang mempelajari bagaimana menghasilkan informasi keuangan untuk pihak manajemen yang akan digunakan untuk pengambilan keputusan. Akuntansi manajemen memiliki peran besar dalam perusahaan karena baik usaha kecil maupun usaha besar membutuhkan informasi akuntansi yang akan digunakan sebagai alat untuk pengawasan maupun dasar pengembilan keputusan karena informasi akuntansi manajemen memiliki cakupan yang luas tidak hanya menyangkut masalah keuangan tetapi juga masalah non keuangan.

Pelaksanaan kegiatan operasional suatu perusahaan membutuhkan sistem pengendalian internal yang baik untuk mencegah dan menghindari terjadinya kesalahan, kecurangan, maupun penyelewengan. Hery (2015:159) menyatakan bahwa sistem pengendalian internal adalah seperangkat kebijakan dan prosedur untuk melindungi aset atau kekayaan perusahaan dari segala bentuk tindakan penyalahgunaan, menjamin tersedianya informasi akuntansi perusahaan yang akurat, serta memastikan bahwa semua ketentuan serta kebijakan manajemen telah dipatuhi atau dijalankan sebagaimana mestinya oleh seluruh karyawan perusahaan. Sujarweni (2015:69) berpendapat bahwa tujuan utama perusahaan membuat sistem pengendalian internal adalah sebagai berikut: (1) untuk menjaga kekayaan perusahaan; (2) untuk menjaga keakuratan laporan keuangan; (3) untuk menjaga kelancaran operasi perusahaan; (4) untuk menjaga kedisiplinan dipatuhinya kebijakan manajemen; dan (5) untuk lapisan yang ada diperusahaan tunduk pada hukum dan aturan yang sudah ditetapkan oleh perusahaan.

Manajemen dapat merancang suatu sistem yang ideal, namun pengendalian tidak akan pernah efektif sepenuhnya meskipun sudah diterapkan dengan sebaik mungkin. Sistem pengendalian internal pada dasarnya akan berjalan dengan baik tergantung pada kemampuan dan kejujuran dari orang-orang yang terlibat di dalamnya. Berikut ini beberapa keterbatasan bawaan yang melekat dalam setiap pengendalian internal di antaranya: (a) kesalahan dalam mempertimbangkan; (b) gangguan; (c) kolusi; dan (d) pengabaian oleh manajemen. Menurut Arens et al. (2015:345), internal control integrated framework yang dikeluarkan COSO, yaitu kerangka kerja pengendalian internal yang paling luas diterima di Amerika Serikat, menguraikan lima komponen pengendalian internal sebagai berikut :

1. Lingkungan pengendalian. Lingkungan pengendalian internal merupakan hal mendasar dalam komponen pengendalian internal. Lingkungan pengendalian menetapkan suasana dari suatu organisasi yang mempengaruhi kesadaran akan pengendalian dari orangorangnya. Lingkungan pengendalian memiliki beberapa elemen penting di antaranya: (a) integritas dan nilai etika; (b) komitmen terhadap kompetensi; (c) partisipasi dewan komisaris atau komite audit; (d) filosofi manajemen dan gaya operasi; (e) struktur organisasi; dan (f) kebijakan dan praktik sumber daya manusia.

2. Penilaian risiko. Penilaian risiko merupakan tindakan manajemen untuk mengidentifikasi dan menganalisis berbagai risiko bisnis yang dapat menghambat perusahaan dalam 
mencapai tujuannya. Risiko dapat berasal dari dalam maupun dari luar perusahaan. Risiko yang berasal dari dalam perusahaan biasanya berkaitan dengan aktivitas tertentu dalam organisasi, seperti karyawan yang tidak terlatih, karyawan yang tidak memiliki motivasi, atau perubahan dalam tanggung jawab manajemen. Sedangkan risiko yang berasal dari luar perusahaan, yaitu tantangan yang berasal dari pesaing, perubahan kondisi ekonomi, kemajuan teknologi, peraturan pemerintah dan bencana alam. Tujuan manajemen mengadakan penilaian risiko adalah untuk menentukan bagaimana cara mengatasi risiko yang telah diidentifikasi.

3. Aktivitas pengendalian. Setelah perusahaan melakukan penilaian risiko dan menentukan cara mengatasi risiko yang telah diidentifikasi, selanjutnya dilakukan aktivitas pengendalian, yaitu berbagai kebijakan dan prosedur yang digunakan untuk memastikan bahwa telah dilakukan tindakan yang tepat untuk menangani risiko. Aktivitas pengendalian dibagi dalam beberapa aktivitas diantaranya: (a) pemisahan tugas; (b) otorisasi; (c) dokumen dan catatan yang memadai; (d) pengendalian fisik atas aset dan catatan; dan (e) pengecekan pekerjaan secara independen.

4. Informasi dan komunikasi. Organisasi memerlukan informasi dan komunikasi dalam mendukung pencapaian tujuan. Manajemen harus memperoleh, menghasilkan, dan menggunakan informasi yang relevan dan berkualitas, baik dari sumber internal maupun eksternal. Hal tersebut diperlukan agar komponen pengendalian internal yang lain berfungsi dengan baik sebagaimana mestinya. Sementara itu, komunikasi merupakan proses untuk memperoleh, membagikan dan menyediakan informasi. Komunikasi harus menjadi sarana diseminasi informasi dalam organisasi, baik dari atasan ke bawahan dan sebaliknya.

5. Pemantauan. Aktivitas pemantauan dilakukan sebagai penilaian berkala atas kualitas pengendalian internal untuk melihat apakah pengendalian telah dijalankan sesuai dengan tujuannya yang kemudian akan dilakukan tindakan perbaikan dan peningkatan atas pengendalian jika diperlukan.

Persediaan sangat penting bagi kelangsungan hidup perusahaan, baik pada perusahaan kecil, menengah, maupun perusahaan pada besar. Persediaan yang dimiliki perusahaan tidak boleh terlalu banyak dan juga tidak boleh terlalu sedikit karena akan mempengaruhi biaya yang akan dikeluarkan untuk persediaan tersebut. Masalah penentuan besarnya persediaan sangatlah penting, karena persediaan memiliki efek langsung terhadap keuntungan perusahaan. Rudianto (2012:222) menyatakan persediaan merupakan salah satu aset perusahaan yang sangat penting karena berpengaruh langsung terhadap kemampuan perusahaan untuk memperoleh pendapatan. Syakur $(2015: 140)$ menyatakan persediaan meliputi segala macam barang yang menjadi objek pokok aktivitas perusahaan yang tersedia untuk diolah dalam proses produksi atau dijual.

Perencanaan dan pengendalian merupakan sesuatu yang tidak dapat dipisahkan dalam pelaksanaan kegiatan. Persediaan membutuhkan pengendalian internal, karena persediaan merupakan bagian penting bagi suatu perusahaan dagang. Pengendalian internal persediaan merupakan semua metode yang tindakan dan pencatatannya dilaksanakan untuk mengamankan persediaan mulai dari proses pemesanan, penerimaan, penyimpanan dan pengeluarannya baik secara fisik maupun secara kualitas, serta penetapan dan pengaturan jumlah persediaan. Herjanto (2014:237) menyatakan bahwa pengendalian internal persediaan dapat didefinisikan sebagai serangkaian kebijakan pengendalian untuk menentukan tingkat persediaan yang harus dijaga, kapan pemesanan untuk menambah persediaan harus dilakukan, dan berapa pesanan yang harus diadakan.

Kalendesang et al. (2017) menunjukkan bahwa pengendalian internal persediaan barang dagang yang diterapkan oleh Paragon Mart Tahuna sudah cukup efektif, di mana adanya pemantauan dan pengecekan barang dagangan setiap hari, serta adanya dokumen- 
dokumen dan catatan transaksi yang memadai. Makikui et al. (2017) menemukan bahwa sistem pengendalian internal atas pengelolaan persediaan yang diterapkan pada CV. Kombos Tendean Manado sudah cukup efektif karena sudah sesuai dengan unsur-unsur pengendalian internal berdasarkan COSO, di mana terdapat pembagian tugas yang memadai serta adanya pengawasan dalam aktivitas operasional perusahaan. Amanda et al. (2015) menunjukkan bahwa pengendalian internal atas persediaan pada Grand Hardware sudah efektif, adanya pemisahan fungsi-fungsi terkait dengan penerimaan dan pengeluaran barang. Pemantauan terhadap persediaan barang dagang dilakukan secara periodik melalui kegiatan stok opname.

\section{METODE PENELITIAN}

Penelitian ini menggunakan jenis deskriptif kualitatif yaitu dengan mendeskripsikan data apa adanya, serta menjelaskan data mengenai informasi bagaimana pelaksanaan sistem pengendalian internal persediaan barang dagangan dengan kalimat penjelasan secara kualitatif. Objek penelitian dilaksanakan pada PT. Daya Anugrah Mandiri Cabang Manado yang beralamat di J1. Babe Palar No. 9, Rike, Wanea, Kota Manado, Sulawesi Utara. Jenis data yang digunakan yaitu data kualitatif berupa gambaran umum perusahaan serta hasil wawancara mengenai pengendalian internal persediaan barang dagangan pada PT. Daya Anugrah Mandiri Cabang Manado.

Sumber data yang digunakan yaitu data primer, di mana data akan diperoleh atau dikumpulkan secara langsung dari PT. Daya Anugrah Mandiri Cabang Manado. Metode pengumpulan data yang dilakukan adalah dokumentasi dan wawancara. Proses analisis pada penelitian ini melalui tahap-tahap sebagai berikut:

1. Mengumpulkan data dengan melakukan wawancara dan dokumentasi berkaitan dengan sistem pengendalian internal persediaan barang dagangan yang diterapkan PT. Daya Anugrah Mandiri Cabang Manado.

2. Mempelajari data yang diperoleh dari objek penelitian.

3. Menganalisis keseluruhan data-data yang diperoleh melalui hasil wawancara dan dokumentasi mengenai penerapan sistem pengendalian internal persediaan barang dagangan pada PT. Daya Anugrah Mandiri Cabang Manado kemudian membandingkannya dengan komponen pengendalian internal berdasarkan COSO apakah sudah berjalan efektif dan efisien.

4. Memberikan kesimpulan dan saran mengenai hasil penelitian yang dilakukan sehingga dapat menjadi masukan bagi PT. Daya Anugrah Mandiri Cabang Manado.

\section{HASIL PENELITIAN DAN PEMBAHASAN}

\subsection{Hasil penelitian}

1. Lingkungan pengendalian. Lingkungan pengendalian sangat penting karena merupakan fondasi dari semua komponen pengendalian internal lainnya yang mencakup seluruh tindakan, kebijakan, dan prosedur yang mencerminkan sikap menyeluruh dari pihak manajemen dan karyawan perusahaan. Lingkungan pengendalian internal yang akan dibahas pada PT. Daya Anugrah Mandiri Cabang Manado adalah berdasarkan COSO di mana memiliki beberapa elemen penting yang dapat dijelaskan sebagai berikut:

a. Integritas dan nilai etika. Perusahaan sangat memperhatikan integritas dan nilai etika dengan membuat kebijakan dan peraturan yang harus dipatuhi. Setiap karyawan harus bersikap sopan baik dari tingkah laku dan cara berbicara, berpakaian sesuai jadwal yang ditetapkan, harus jujur dalam melakukan tugas dan pekerjaan, serta disiplin terhadap kehadiran untuk datang tepat waktu sesuai dengan ketentuan yang ditetapkan perusahaan. Apabila ditemukan pelanggaran, akan diberikan peringatan serta sanksi terhadap karyawan yang melakukan pelanggaran. 
b. Komitmen terhadap kompetensi. Perusahaan menetapkan kriteria tertentu dalam merekrut karyawan baru, yaitu dengan mempertimbangkan keahlian, pendidikan, serta melihat pengalaman kerja yang dimiliki calon pekerja. Hal ini dilakukan dengan tujuan agar karyawan yang dipekerjakan memiliki keahlian serta pendidikan yang sesuai dengan bidang pekerjaan yang nantinya akan diserahkan, dan diharapkan dalam melaksanakan pekerjaan dapat dilakukan dengan efektif dan efisien sehingga aktivitas yang terjadi dalam perusahaan dapat berjalan lancar karena setiap karyawan mengerti dengan baik tugas dan tanggung jawab yang harus mereka selesaikan.

c. Partisipasi dewan komisaris atau komite audit. Dewan komisaris atau komite audit dari PT. Daya Anugrah Mandiri berkedudukan di kantor pusat yang terletak di Bandung. Tim audit dari kantor pusat akan melakukan pemeriksaan pada saat-saat tertentu terhadap jalannya kegiatan operasional kantor cabang dengan meminta laporan rutin dari pihak manajemen kantor cabang dan mengevaluasinya.

d. Filosofi dan gaya operasi manajemen. Filosofi dan gaya operasi manajemen menunjukkan seperangkat keyakinan dasar yang menjadi tolak ukur perusahaan dan karyawan dalam menetapkan tujuan dan pelaksanaan bisnis perusahaan. PT. Daya Anugrah Mandiri Cabang Manado memiliki filosofi pelayanan yaitu "Memberikan solusi yang Handal, Lengkap, Mudah dan penuh Keakraban (HALMA)".

e. Struktur organisasi. Struktur organisasi merupakan salah satu faktor yang turut mempengaruhi tingkat keberhasilan suatu perusahaan dalam mencapai tujuan yang ditetapkan. Agar kegiatan operasional perusahaan dapat berjalan lancar maka pembagian tugas dan tanggung jawab masing-masing bagian harus ditetapkan dalam struktur organisasi perusahaan. Bentuk struktur organisasi pada PT. Daya Anugrah Mandiri Cabang Manado disusun secara fungsional di mana penyusunan pembagian tugas dan wewenang dari setiap fungsional sudah jelas.

f. Kebijakan dan praktik sumber daya manusia. Kebijakan dan praktik sumber daya manusia berperan penting bagi jalannya pengawasan karena karyawan merupakan komponen penting dalam pelaksanaan pengendalian internal perusahaan. Perusahaan menetapkan kriteria tertentu dalam merekrut karyawan baru, dan melakukan program pelatihan kepada karyawan baru dengan tujuan untuk menghasilkan tenaga kerja yang berkemampuan tinggi dalam melaksanakan tugas yang dikerjakan, serta memberikan penghargaan secara khusus bagi karyawan yang berprestasi.

2. Penilaian risiko. Berikut beberapa penilaian risiko yang dilakukan PT. Daya Anugrah Mandiri Cabang Manado serta pengantisipasiannya, baik risiko yang mungkin terjadi dari dalam maupun dari luar perusahaan yaitu:

a. Kerusakan barang dagangan. Saat menerima persediaan berupa unit motor sering ditemui kerusakan, seperti pada bagian kaca lampu motor sering terdapat retakan atau pecah yang mungkin disebabkan unit motor saling terbentur saat dalam perjalanan. Pada saat menerima barang untuk masuk ke gudang akan dilakukan pengecekan secara teliti oleh staf bagian gudang dibantu petugas keamanan dan staf pemasok (main dealer) untuk memastikan barang yang diterima dalam keadaan baik. Begitu juga dengan persediaan barang dagangan yang ada di gudang akan dilakukan pengecekan secara berkala.

b. Kecurangan karyawan. Perusahaan menyadari akan adanya risiko kecurangan yang mungkin dilakukan oleh pihak yang tidak bertanggung jawab, terlebih perusahaan tidak memasang kamera pengawas di gudang tempat penyimpanan. Kecurangan ini dapat berupa pencurian terutama pada persediaan suku cadang yang berukuran kecil seperti busi motor. Perusahaan melakukan inspeksi mendadak terhadap persediaan barang dagang yang ada di gudang khususnya persediaan suku cadang yang berukuran kecil. 
c. Masa pakai. Pada persediaan suku cadang, seperti aki dan ban motor harus diperhatikan masa pakainya, dilakukan pengecekan terhadap tanggal produksi barang kemudian disusun sesuai jenis dan tanggal sehingga mempermudah saat pengambilan barang. Selain risiko dari dalam perusahaan, ada juga risiko yang dapat disebabkan dari luar perusahaan, yaitu banyaknya pesaing-pesaing baru bermunculan yang bergerak di bidang yang sama. Perusahaan berupaya untuk terus meningkatkan kualitas sumber daya manusia, menjaga kualitas persediaan, mengutamakan kepuasan pelanggan baik terhadap kualitas produk yang ditawarkan serta kepuasan terhadap layanan yang diberikan, di mana perusahaan melakukan strategi dengan menyediakan air mineral, kopi, teh, dan permen bagi pelanggan yang datang.

3. Aktivitas pengendalian. Aktivitas pengendalian pada PT. Daya Anugrah Mandiri Cabang Manado meliputi berbagai kebijakan dan prosedur yang ditetapkan untuk dapat menjamin bahwa sistem tersebut telah berjalan efektif. Aktivitas pengendalian yang dijalankan yaitu sebagai berikut:

a. Pemisahan tugas: (1) aktivitas pemesanan barang dilakukan oleh bagian administrasi; (2) aktivitas penerimaan dan penyimpanan barang dilakukan oleh bagian gudang; (3) aktivitas pencatatan oleh bagian administrasi; (4) aktivitas pembayaran dilakukan oleh bagian kasir; dan (5) aktivitas pengeluaran barang dilakukan oleh bagian gudang.

b. Otorisasi transaksi. Otorisasi atas transaksi dilakukan dengan pembubuhan tanda tangan oleh pihak yang berwenang pada dokumen untuk menyetujui terjadinya aktivitas transaksi tersebut. Otorisasi atas transaksi pada PT. Daya Anugrah Mandiri Cabang Manado dapat dilihat sebagai berikut: (1) aktivitas pemesanan barang, purchase order diotorisasi oleh kepala cabang; (2) aktivitas penerimaan barang, surat bukti penerimaan barang diotorisasi oleh Kepala Administrasi/Administration Head (ADH); dan (3) aktivitas pengeluaran barang, sales order diotorisasi oleh kepala cabang.

c. Dokumen dan catatan yang memadai. Terdapat berbagai macam dokumen dan catatan yang berkaitan dengan pemesanan dan pengeluaran persediaan, misalnya pada aktivitas pemesanan barang terdapat dokumen berupa purchase order, pada aktivitas pengeluaran barang terdapat dokumen berupa sales order, pada aktivitas penerimaan barang terdapat dokumen berupa surat jalan. Dokumen-dokumen tersebut berisikan data berupa nama pemasok atau pembeli, tanggal pemesanan atau pembelian, kolom kode barang, tipe atau jenis barang, warna, jumlah barang, harga barang, dan data lainnya yang diperlukan.

d. Pengendalian fisik atas aset dan catatan. Untuk perlindungan aset dan catatan maka perusahaan menyediakan gudang sebagai tempat penyimpanan yang dilengkapi alat pemadam api (fire extinguisher) untuk menanggulangi bahaya kebakaran, dan saat jam kerja selesai gudang akan dikunci oleh karyawan yang berwenang. Perlindungan fisik terhadap dokumen dan catatan dilakukan dengan mengarsipkan dokumen dan catatan ke dalam binder map kemudian disimpan dalam lemari arsip.

e. Pengecekan pekerjaan secara independen. Perusahaan melakukan pengecekan terhadap pekerjaan pada tiap bagian atau bidang yang dilakukan oleh ADH. Kebijakan perusahaan lewat pemeriksaan secara tidak langsung menciptakan suatu pengecekan yang independen terhadap kinerja menyangkut pengelolaan persediaan mulai dari permintaan sampai pengeluaran barang dalam perusahaan.

4. Informasi dan komunikasi. Sistem informasi dan komunikasi menyangkut aktivitas pemesanan, penerimaan, dan pengeluaran persediaan barang dagangan pada PT. Daya Anugrah Mandiri Cabang Manado dilaksanakan sesuai prosedur yang ditetapkan. Adanya dokumen dan catatan yang diperlukan, serta laporan yang dihasilkan harus didasarkan atas laporan yang telah dilampiri dengan dokumen pendukung yang lengkap serta 
diotorisasi oleh pihak berwenang sehingga dapat menjadi informasi yang akurat bagi manajemen menyangkut persediaan barang. Informasi dan komunikasi yang baik dapat mendukung terciptanya akuntabilitas terhadap aset perusahaan (Mamentu dan Budiarso, 2018). Sistem ini diterapkan pada PT. Daya Anugrah Mandiri Cabang Manado dengan melakukan pelaporan setiap hari saat briefing pagi sebagai informasi mengenai catatan persediaan yang meliputi jumlah penjualan, target dan total pemasaran yang dicapai. PT. Daya Anugrah Mandiri Cabang Manado sudah menggunakan sistem yang terkomputerisasi, sehingga memperkecil kemungkinan terjadinya keterlambatan informasi dan komunikasi bagi pihak perusahaan.

5. Pemantauan. Pemantauan merupakan faktor penting untuk kemajuan perusahaan yang dilakukan agar dapat mengetahui serta menilai kualitas pelaksanaan pengendalian internal yang diterapkan dalam perusahaan. PT. Daya Anugrah Mandiri Cabang Manado melakukan pemeriksaan secara rutin seluruh pelaksanaan kegiatan perusahaan untuk menilai apakah aktivitas perusahaan telah berjalan sesuai dengan prosedur yang telah ditetapkan. Pengawasan terhadap persediaan barang dagangan dilakukan dengan melakukan kegiatan stock opname, apabila ditemukan penyimpangan dalam pelaksanaan kegiatan perusahaan terutama pada aktivitas yang menyangkut persediaan barang dagangan, akan dicari tahu kebenarannya sampai tuntas.

\subsection{Pembahasan}

\section{Lingkungan pengendalian}

a. Integritas dan nilai etika. Integritas dan nilai etika pada PT. Daya Anugrah Mandiri Cabang Manado telah diterapkan dan dijalankan dengan baik karena setiap karyawan telah mematuhi peraturan yang ditetapkan. Perusahaan membuat peraturan dan kebijakan dengan tujuan untuk menjadikan karyawan yang berintegritas dan memiliki nilai etika yang baik, di mana mengharuskan setiap karyawan untuk bersikap sopan baik dari cara berbicara maupun berpakaian, jujur dalam melakukan tugas dan pekerjaan, serta disiplin terhadap kehadiran untuk datang tepat waktu sesuai dengan ketentuan yang ditetapkan perusahaan.

b. Komitmen terhadap kompetensi. PT. Daya Anugrah Mandiri Cabang Manado menetapkan kriteria tertentu dalam merekrut karyawan baru, yaitu dengan mempertimbangkan keahlian, pendidikan, serta melihat pengalaman kerja yang dimiliki calon pekerja. Hal ini dilakukan dengan tujuan agar karyawan yang dipekerjakan memiliki keahlian serta pendidikan yang sesuai dengan bidang pekerjaan yang nantinya akan diserahkan, dan diharapkan dalam melaksanakan pekerjaan dapat dilakukan dengan efektif dan efisien. Sehingga aktivitas yang terjadi dalam perusahaan dapat berjalan lancar karena setiap karyawan mengerti dengan baik tugas dan tanggung jawab yang harus mereka selesaikan. Dari penjelasan di atas dapat dikatakan bahwa penerapan terhadap komponen ini telah dilakukan dengan efektif.

c. Partisipasi dewan komisaris atau komite audit. Dewan komisaris atau komite audit dari PT. Daya Anugrah Mandiri berkedudukan di kantor pusat yang terletak di Bandung. Tim audit dari kantor pusat akan melakukan pemeriksaan pada saatsaat tertentu terhadap jalannya kegiatan operasional kantor cabang dengan cara meminta laporan rutin dari pihak manajemen kantor cabang dan mengevaluasinya. Hal ini cukup memadai karena PT. Daya Anugrah Mandiri Cabang Manado merupakan perpanjangan operasional dari PT. Daya Anugrah Mandiri.

d. Filosofi manajemen dan gaya operasi. Berdasarkan hasil penelitian, filosofi dan gaya operasi manajemen PT. Daya Anugrah Mandiri Cabang Manado telah dilakukan dengan baik. PT. Daya Anugrah Mandiri Cabang Manado memiliki filosofi yaitu "Memberikan solusi yang Handal, Lengkap, Mudah dan penuh 
Keakraban (HALMA)". Dapat dilihat adanya keseriusan dari perusahaan untuk berusaha menyediakan kebutuhan akan persediaan dengan kualitas terbaik serta layanan yang prima.

e. Struktur organisasi. Struktur organisasi pada PT. Daya Anugrah Mandiri Cabang Manado telah dirancang dan disusun dengan baik, yaitu secara fungsional. Di mana penyusunan ini sudah jelas dalam pembagian tugas dan wewenang dari setiap fungsional yang ada di perusahaan. Salah satu kekurangan pengendalian intern pada PT. Daya Anugrah Mandiri Cabang Manado tidak memiliki bagian akuntansi untuk melakukan pencatatan dan pembuatan laporan keuangan, fungsi ini dirangkap oleh bagian kasir.

f. Kebijakan dan praktik sumber daya manusia. Kebijakan dan praktik sumber daya manusia pada PT. Daya Anugrah Mandiri Cabang Manado terlihat sudah berjalan efektif. Perusahaan telah menerapkan kebijakan dalam merekrut karyawan baru, melakukan training bagi karyawan baru, serta adanya reward yang secara khusus diberikan kepada karyawan yang berprestasi. Kebijakan seperti ini sudah baik untuk membina kualitas karyawan yang jujur, sopan, dan terampil, serta mendorong karwayan untuk dapat lebih bekerja keras. Daft (2014:122) mengemukakan bahwa pelatihan (training) merupakan upaya terencana yang dilakukan perusahaan untuk memfasilitasi karyawan mempelajari berbagai keterampilan yang berhubungan dengan pekerjaan.

2. Penilaian risiko. Penilaian risiko yang dilakukan PT. Daya Anugrah Mandiri Cabang Manado menyangkut persediaan barang dagangan sudah dilakukan dengan baik. Manajemen perusahaan telah melakukan penilaian terhadap risiko-risiko yang mungkin terjadi, baik yang disebabkan dari dalam maupun dari luar perusahaan serta memikirkan cara pengantisipasiannya dalam menghadapi hal tersebut. PT. Daya Anugrah Mandiri Cabang Manado mampu bertahan karena mengutamakan kepuasan pelanggan dan mempertahankan kualitas barang dagangan yang dipasarkan, sehingga mendapat respon baik pula dari para konsumen dan tetap eksis sampai sekarang. Menurut Djohanputro (2014:43) manajemen risiko merupakan proses terstruktur dan sistematis dalam mengidentifikasi, mengukur, dan mengembangkan alternatif penanganan risiko.

3. Aktivitas pengendalian. Aktivitas pengendalian pada PT. Daya Anugrah Mandiri sudah berjalan dengan baik. Namun masih terdapat beberapa hal yang harus diperhatikan perusahaan.

a. Pemisahan tugas yang memadai. PT. Daya Anugrah Mandiri Cabang Manado telah mengadakan pemisahan tugas pada setiap kegiatan yang berkaitan dengan persediaan barang dagangan, sehingga hal ini dapat menciptakan pengendalian internal yang memadai dalam perusahaan. Adanya pemisahan tugas pada setiap bagian dengan fungsi kerja masing-masing mulai dari aktivitas permintaan sampai pengeluaran barang, dapat menghindari peluang dalam melakukan kecurangan atau manipulasi terhadap persediaan.

b. Otorisasi transaksi. Otorisasi atas transaksi dan aktivitas pada PT. Daya Anugrah Mandiri Cabang Manado telah diterapkan dengan efektif. Setiap transaksi dan aktivitas yang dilakukan harus diotorisasi dahulu oleh pihak yang berwenang. Tanpa diotorisasi terlebih dahulu, setiap transaksi dan aktivitas tersebut akan dianggap tidak sah. Hal ini sudah baik dalam berlangsungnya pengendalian internal terhadap persediaan barangan dagangan. Mulyadi (2013:164) setiap transaksi hanya terjadi atas dasar otorisasi dari pejabat yang memiliki wewenang untuk menyetujui terjadinya transaksi tersebut. 
c. Dokumen dan catatan yang memadai. Dokumen dan catatan pada PT. Daya Anugrah Mandiri Cabang Manado sudah memadai, sehingga dapat dikatakan sudah efektif. Setiap transaksi yang dilakukan membutuhkan dokumen serta dicatat secara terperinci agar tidak terjadi kecurangan atau penyelewengan. Dengan adanya dokumen dan catatan yang memadai, dapat memudahkan dalam mengontrol keberadaan barang dagangan yang ada. Mulyadi (2013:165) menyatakan bahwa prosedur harus mencakup perancangan dan penggunaan dokumen dan catatan yang memadai untuk membantu meyakinkan adanya pencatatan transaksi dan kejadian secara memadai.

d. Pengendalian fisik atas aset dan catatan. Pengendalian fisik atas persediaan barang dagangan serta dokumen dan catatan pada PT. Daya Anugrah Mandiri Cabang Manado sudah baik, yaitu dengan tersedianya gudang sebagai tempat penyimpanan persediaan, dan untuk dokumen dan catatan disimpan dalam lemari arsip. Terdapat kelemahan dalam hal perlindungan atas persediaan, dimana perusahaan tidak menggunakan kamera pengawas di gudang tempat penyimpanan persediaan. Dengan penggunaan kamera pengawas dapat lebih membantu perusahaan untuk melindungi persediaan dan memperkecil terjadinya pencurian terhadap persediaan barang dagangan yang ada di gudang. Mulyadi (2013:165) menyatakan bahwa pengawasan fisik berhubungan dengan penggunaan alat-alat mekanis dan elektronis dalam pelaksanaan dan pencatatan transaksi.

e. Pengecekan pekerjaan secara independen. Aktivitas pengecekan pekerjaan pada PT. Daya Anugrah Mandiri Cabang Manado sudah baik. ADH selalu melakukan pengecekan terhadap persediaan barang dagangan maupun dokumen dan catatan yang berkaitan dengan aset perusahaan, serta melakukan pengecekan terhadap pekerjaan semua karyawan. Semua upaya yang dilakukan manajemen PT. Daya Anugrah Mandiri Cabang Manado sudah baik dalam menjaga aset perusahaan dan membawa setiap karyawan agar mampu menjalankan tanggung jawab pekerjaan dengan baik. Hal ini sudah cukup baik dalam menunjang pelaksanaan pengendalian internal.

4. Informasi dan komunikasi. Sistem informasi dan komunikasi pada PT. Daya Anugrah Mandiri Cabang Manado sudah efektif. Hal ini dapat dilihat dari penyusunan prosedur yang dibuat sudah jelas, termasuk dalam prosedur menyangkut persediaan barang dagangan yang memerlukan dokumen dan catatan, serta laporan yang dihasilkan harus didasarkan atas laporan sumber yang dilampiri dengan dokumen pendukung yang lengkap dan diotorisasi oleh pihak yang berwenang sehingga dapat menjadi informasi yang akurat bagi manajemen menyangkut persediaan barang. PT. Daya Anugrah Mandiri Cabang Manado sudah menggunakan sistem yang terkomputerisasi sehingga tidak memperlambat dalam memperoleh informasi dan komunikasi bagi pihak perusahaan. Serta adanya komunikasi antara dua arah atau komunikasi timbal balik yang baik antara pimpinan dan karyawan, sehingga ketika terjadi masalah dapat langsung dibicarakan dan diselesaikan. Komunikasi dianggap perlu untuk mengetahui kelemahan pengendalian internal dan dapat diambil tindakan perbaikan. Mulyadi (2013:165) informasi dan komunikasi adalah pengidentifikasian, pengungkapan, dan pertukaran informasi dalam suatu bentuk dan waktu yang memungkinkan orang melaksanakan tanggung jawab mereka.

5. Pemantauan. Pemantauan yang dilakukan PT. Daya Anugrah Mandiri Cabang Manado sudah berjalan dengan baik untuk mendukung terciptanya pengendalian internal yang memadai dalam perusahaan. Adanya pemeriksaan secara rutin seluruh pelaksanaan kegiatan perusahaan untuk menilai apakah aktivitas perusahaan telah berjalan sesuai dengan prosedur yang telah ditetapkan. Pengawasan terhadap 
persediaan barang dagangan dilakukan dengan adanya kegiatan stock opname, apabila ditemukan penyimpangan dalam pelaksanaan kegiatan perusahaan terutama pada aktivitas yang menyangkut persediaan barang dagangan, akan dicari tahu kebenarannya sampai tuntas. Mulyadi (2013:166) menyatakan bahwa pengawasan adalah proses yang menentukan kualitas kinerja pengendalian internal sepanjang waktu yang dilakukan pemimpin perusahaan.

\section{KESIMPULAN DAN SARAN}

\subsection{Kesimpulan}

Berdasarkan hasil penelitian dan pembahasan, sistem pengendalian internal atas persediaan barang dagangan yang diterapkan PT. Daya Anugrah Mandiri Cabang Manado terkait lima komponen pengendalian internal berdasarkan COSO, yaitu lingkungan pengendalian, penilaian risiko, aktivitas pengendalian, informasi dan komunikasi, serta pengawasan, secara keseluruhan dapat disimpulkan bahwa penerapannya sudah efektif. Namun masih terdapat beberapa kekurangan, seperti dalam komponen lingkungan pengendalian khususnya pada struktur organisasi dari PT. Daya Anugrah Mandiri Cabang Manado yang belum memiliki bagian akuntansi, di mana bagian ini adalah bagian yang penting dalam suatu perusahaan. Pada aktivitas pengendalian khususnya pengendalian fisik atas aset dan catatan, dimana gudang tempat penyimpanan persediaan barang dagangan tidak terdapat kamera pengawas yang dapat membantu perusahaan dalam melindungi persediaan serta memperkecil terjadinya pencurian terhadap persediaan barang dagangan yang ada di gudang.

\subsection{Saran}

1. PT. Daya Anugrah Mandiri Cabang Manado perlu membentuk Bagian Akuntansi agar setiap pencatatan dan laporan keuangan bisa lebih jelas dan terperinci.

2. PT. Daya Anugrah Mandiri Cabang Manado sebaiknya memasang kamera pengawas di gudang tempat penyimpanan persediaan, agar dapat lebih membantu perusahaan dalam melindungi persediaan serta memperkecil terjadinya pencurian terhadap persediaan barang dagangan yang ada di gudang.

\section{DAFTAR PUSTAKA}

Amanda, C., Sondakh, J. J., \& Tangkuman, S. J. (2015). Analisis efektivitas sistem pengendalian internal atas persediaan barang dagang pada Grand Hardware Manado. Jurnal EMBA: Jurnal Riset Ekonomi, Manajemen, Bisnis dan Akuntansi, 3(3), 766776. https://ejournal.unsrat.ac.id/index.php/emba/article/view/9609.

Arens, A. A., Elder, R. J., \& Beasley, M. S. (2015). Auditing dan jasa assurans pendekatan terintegrasi, Jilid 1, Edisi kelima belas. Jakarta: Erlangga.

Daft, R. (2014). Era baru manajemen. Jakarta: Salemba Empat.

Djohanputro, B. (2014). Manajemen risiko korporat terintegrasi. Jakarta: PPM.

Herjanto, E. (2014). Manajemen operasi, Edisi ketiga. Jakarta: Grasindo.

Hery. (2015). Auditing 1: Dasar-dasar pemeriksaan akuntansi, Cetakan ketiga. Jakarta: Prenada Media.

Kalendesang, A. K., Lambey, L., \& Budiarso, N. S. (2017). Analisis efektivitas sistem pengendalian internal persediaan barang dagang pada Supermarket Paragon Mart Tahuna. Going Concern: Jurnal Riset Akuntansi, 12(2), 131-139. https://ejournal.unsrat.ac.id/index.php/gc/article/view/17443.

Kartikahadi, H. (2016). Akuntansi keuangan berdasarkan SAK berbasis IFRS, Buku 1. Jakarta: Salemba Empat. 
Makaluas, J. L., \& Pontoh, W. (2018). Ipteks pengendalian intern aset tetap pada PT. Lumbung Berkat Indonesia. Jurnal Ipteks Akuntansi bagi Masyarakat, 2(1), 1-5. https://doi.org/10.32400/jiam.2.1.2018.19640.

Makikui, L. E., Morasa, J., \& Pinatik, S. (2017). Analisis sistem pengendalian internal atas pengelolaan persediaan berdasarkan COSO pada CV. Kombos Tendean Manado. Going Concern: Jurnal Riset Akuntansi, 12(2), 1222-1232. https://doi.org/10.32400/gc.12.2.18695.2017.

Mamentu, T. P. M., \& Budiarso, N. S. (2018). Ipteks pengendalian intern terhadap aset tetap di Kantor Pengawasan dan Pelayanan Bea dan Cukai Tipe Madya Pabean C/KPPBC TMP C Bitung, Jurnal Ipteks Akuntansi bagi Masyarakat, 2(2), 570-754. https://doi.org/10.32400/jiam.2.02.2018.21833.

Mulyadi. (2013). Sistem akuntansi, Edisi ketiga. Jakarta: Salemba Empat.

Pontoh, W. (2013). Akuntansi konsep dan aplikasi. Jakarta: Halaman Moeka.

Rudianto. (2012). Pengantar akuntansi konsep \& teknik penyusunan laporan keuangan adaptasi IFRS. Jakarta: Erlangga.

Sujarweni, V. W. (2015). Sistem akuntansi. Bandung: Pustaka Baru Press.

Sujarweni, V. W. (2016). Akuntansi manajemen teori dan aplikasi. Bandung: Pustaka Baru Press.

Syakur, A. S. (2015). Intermediate accounting: Dalam perspektif lebih luas, Edisi revisi. Jakarta: Pembuka Cakrawala. 